\title{
RECENT DEVELOPMENTS IN EDIBLE COATINGS FOR FRESH FRUITS AND VEGETABLES
}

\author{
A review \\ Neegam NAIN, Gunjan K. KATOCH, Sawinder KAUR*(D), Prasad RASANE \\ Lovely Professional University, India
}

Received: December 2020; Accepted: November 2021

\begin{abstract}
The world population is elevating rapidly, the demand for fruits and vegetables is increasing due to their nutritional value, and the concerns regarding the quality have been amplified. Therefore, the development of various techniques to retain quality attributes, and shelf-life extension of food has become a focal point for researchers and food industries. One of the economical techniques used for the preservation of food is the application of edible coating onto the surface of fresh or minimally processed fruits and vegetables. The foremost advantage of edible coating is that it is eco-friendly. Edible coatings can improve nutritional quality along with the maintenance of physiological attributes of fruits and vegetables. It can also act as a vehicle to carry active components, such as essential oils and spices that also carry antioxidant and antimicrobial properties. The application of nanotechnology for the formulation of edible coating is playing a significant role and aids in the reduction of microbial load on fruits and vegetables. The main aim of this review is to bring up-to-date information regarding various edible coatings used on minimally processed fruits and vegetables - carbohydrates, proteins, lipids, composites, fruit purees, and herb-based edible coatings and their significant effect on the physiological properties of produces. The information will be beneficial for the researchers and scholars to study the various effects of edible coatings on minimally processed fruits and vegetables.
\end{abstract}

Key words: antimicrobial compounds, edible coatings, fabrication, functional coatings, preservation of fresh fruits and vegetables

\section{INTRODUCTION}

Various technologies have been developed in the market to combat the challenge of delivering fresh fruits and vegetables to consumers' plates (Tahir et al. 2019). Edible coating aids in maintaining freshness and enhances the shelf life of fresh or minimally processed fruits and vegetables (Pavlath \& Orts 2009; Tahir et al. 2019). An edible coating is defined as a thin layer of edible material covering the food commodity, it is usually applied via dipping the commodity into the coating solution or by spraying. It suppresses moisture loss and preserves the sensory quality of fruits and vegetables.
It also helps to make the product more attractive by providing a shiny texture to the waxed surfaces of the fruit (Lin \& Zhao 2007; Kang et al. 2013).

Fruits and vegetables have a short shelf life and are highly susceptible to physiological and biochemical damage (Sapper \& Chiralt 2018). Previously, synthetic waxes and fungicides were used to protect against degradation of the postharvest shelf life and to extend the shelf life. The major disadvantage of these treatments is their negative impact on health and the environment, which has led to the development of edible coating and films made of naturally occurring biopolymers that have proven to be environmentally and user-friendly materials (Karaca et al. 2014; Jemilakshmi et al. 2020). 
Nowadays researchers are focusing on finding suitable raw materials for edible coatings and films that are ecologically friendly and safe for consumers. Edible coatings can be fabricated using several natural polymers, for example polysaccharides, which include starch, alginate, dextrose, chitosan, cellulose, and pectin (Hassan et al. 2018). These polymers also act as carriers for functional components (Mehyar et al. 2014; Corbo et al. 2015) such as antimicrobials, antioxidants and antibrowning agents, vitamin E, spices, and food stabilizers that can be incorporated into edible coatings (Fagundes et al. 2015).

Farm food is best eaten directly. However, as the demand for nonseasonal fruit and vegetable increases, it is necessary to store food longer (Embuscado \& Huber 2009). The system of distributing food from farms to consumers' tables has been improved; therefore the main responsibility of the distributor is to preserve the sensory qualities and freshness of the food. Edible coating aids in reducing product loss during storage and transportation to a noteworthy extent. The deterioration of food production increases to a notable level during storage and transportation, and if appropriate precautions are not taken, the product will be unappealing to consumers; thus, the food industry will face huge losses (Embuscado \& Huber 2009). The aim of this review is to provide up-to-date information regarding the application of edible coatings and their significant effects on the physiological properties of fruits and vegetables.

\section{Fabrication and deposition of edible coatings and films}

Edible films serve as a conveyance for delivering active components, flavors, drugs, and nutraceuticals (Wongphan \& Harnkarnsujarit 2020). These active components are trapped in the biopolymer matrix and remain stable until reaching the consumer's table. Edible films are fabricated from biopolymers using wet and dry processes. The wet process is solvent casting; whereas, the dry process is also known as the extrusion process (Siemann 2005; Suhag et al. 2020). Edible coatings are generally prepared from the substance pertaining to film-forming properties. The raw material for formulating the edible coating must be able to be dispersed and dissolved in the desired solvent, for example water, alcohol and a mixture of solvents in the desired ratio. While preparing edible coating plasticizers, antimicrobial agents, flavor-enhancing substances, vitamins, colors, and spices can also be incorporated (Dhall 2013; Raghav et al. 2016). Plasticizers are blended into the solution of edible coating to increase the mechanical strength (Sothornvit \& Krochta 2005) and to provide flexibility to the films and coatings (Hassan et al. 2018). Water acts as a natural plasticizer for edible coatings and films. Glycerol, sorbitol, fatty acids, sucrose, polyethylene glycol (PEG), propylene glycol (PG), and monoglycerides are good options to provide flexibility and plasticizers (Krochta 2002; Sothornvit \& Krochta 2005).

\section{Casting method}

The casting method or solvent casting method is commonly exercised at the pilot scale. The main steps involved in this method are solubilization of biopolymer into suitable solvent followed by casting into suitable molds and drying (Jensen et al. 2015; Suhag et al. 2020). The casting method provides fewer defects due to its homogenous nature, and the manufacturing method is cost-efficient (Chen et al. 2008; Yang et al. 2011). The method contributes to appreciable optical purity and good transparency (Suhag et al. 2020). The salient disadvantage of casting methods is that proteins and other components get degraded by the use of solvent, the amount of film fabricated is limited, film development is dependent on the temperature and evaporative range, and it is a time-consuming technique. Therefore, it is not recommended for commercial use (Sait \& Ma 2009; Fakhouri et al. 2013; Jensen et al. 2015; Suhag et al. 2020).

\section{Extrusion method}

The extrusion method (dry process) for the development of edible films is used at a commercial scale. The extrusion process takes place in three different stages: a) feeding stage, b) kneading stage, and c) heating stage. The extrusion process is also referred to as the dry process because the least amount of water or solvent is required during the feeding zone to obtain an optimal result (Peressini et al. 2003; Calderón-Castro et al. 2018). The extrusion method takes a short processing time, least solvent, 
and low energy expenditure. This method is recommended for commercial purposes, and the final product has high mechanical and optical properties (Raghav et al. 2016). The major drawbacks of using the extrusion method are: its high initial cost, requirements to skilled workers, biopolymer used must be temperature tolerant, and low moisture content (Raghav et al. 2016; Suhag et al. 2020).

\section{Deposition of edible coating}

The deposition of the edible coating on the food product depends on the nature and the surface attributes of the food product to be coated (Suhag et al. 2020). Edible coatings can be deposited over the fruits and vegetables by various techniques, such as dipping, spraying, fluidized bed, and panning (Raghav et al. 2016; Suhag et al. 2020). The application of an edible coating by the brushing method has been found to have valuable results on both less perishable vegetables such as beans and extremely perishable fruits such as strawberries and berries (Valverde et al. 2005; Raghav et al. 2016). The dipping process involves the immersion of food products directly into the edible coating solution followed by drying in which the solvent gets evaporated (Andrade et al. 2012; Senturk Parreidt et al. 2018). The spraying technique is the widely used technique for the application of edible coating over food products. Droplets are formed and then distributed over the food surface via nozzles. Air spray atomization, air-assisted airless atomization, and pressure atomization are the major spraying techniques practiced at the industrial scale (Andrade et al. 2012; Valdés et al. 2017). The low density or small size dry particles are usually thinly coated using the fluidized-bed technique. This process is categorized into three types; (i) top spray, (ii) bottom spray, and (iii) rotary fluidized bed. The top-spraying fluidized technique is highly effective in food industries (Suhag et al. 2020). The coating or layering solution is sprinkled onto the rotating bowl in which the product is placed. It is followed by drying of the coating layer (Pandey et al. 2006). Hard panning is the application of a hard shell by continuous treatment with sugar syrup on the surface of the product. Soft panning involves the administration of a mixture of corn syrup and sugar for coating followed by the application of dry sugar. Chocolate panning involves the use of fat-based layers such as cocoa-based or white chocolate (Gesford 2002).

\section{Polysaccharide-based edible coatings and its de- rivatives}

Polysaccharides are widely used for the fabrication of edible coatings and films to enhance the shelf life and quality retention of food products. They are proven to possess good oxygen barrier properties but are hydrophilic in nature; edible coatings derived from polysaccharides lack satisfactory moisture barrier properties (Hassan et al. 2018; Yousuf et al. 2018). Polysaccharide-based edible coatings are colorless and constitute less caloric content and in addition to that can be used to extend the shelf life of food products such as fruits, vegetables, and meat (Hassan et al. 2018). Edible coatings resulting from polysaccharides include cellulose and its derivatives, such as methylcellulose, hydroxypropyl cellulose, hydroxypropyl methyl cellulose, methyl ethyl cellulose, carboxyl methylcellulose, starches (derived from different sources), dextrin, pectin derivatives, pullulan, alginate, chitin, and chitosan-based edible coatings, gums - Arabic gum, guar gum, xanthan gum, carrageenan, and agar (Raghav et al. 2016; Hassan et al. 2018; Yousuf et al. 2018; Salehi 2020). The major advantage of using starch-based coatings is that they are colorless, provide an oil-free exterior, it is readily available, and the cost is low, which makes it a promising polymer for an edible coating (Luchese et al. 2017); thus, it can be used to enhance the shelf life of fruits and vegetables. Starch cannot be used solely for the preparation of edible coating due to its hydrophilic nature, which makes it water-sensitive and decreases water vapor barrier capacity; therefore, plasticizers and emulsifiers are added to improve the flexibility and barrier properties (Cazón et al. 2017). Table 1 summarizes the application of various types of edible coatings on fruits and vegetables.

Protein-based edible coatings and its derivatives Globular and fibrous proteins happen to be found naturally. Milk protein, that is, casein protein and whey protein, are suitable raw materials for the formulation of edible coatings (Mohamed et al. 2020). Edible coatings and films derived from protein exhibit outstanding barriers against carbon dioxide 
and oxygen but do not possess great mechanical strength (Yousuf et al. 2018). Almond and walnut oil can be incorporated to enhance the barrier properties (Hassan et al. 2018). Proteins such as soy protein, corn zein, wheat gluten, gelatin are also promising substitutes for protein-based edible films to preserve the quality of products (Hassan et al. 2018; Yousuf et al. 2018). Zein is majorly extracted from corn; it is a raw material for the preparation of edible films and coatings. Protein-based edible coatings derived from zein display significant barriers against moisture, and by the addition of fatty acids, zein coatings can provide a good barrier against water vapor loss (Hassan et al. 2018). Fish protein such as Whitemouth croaker protein isolate along with organoclay Montmorillonite (MMT) demonstrated great potential in extending the shelf life of minimally processed papaya (Cortez-Vega et al. 2014). Lipid-based edible coatings and its derivatives Lipids are ideal choices as constituents in edible films and coatings due to the necessity to prevent moisture losses by packaged or nonpackaged food items. Lipids are generally combined with polysaccharides or proteins to improve their functionality in edible films or coatings. The most commonly used lipid compounds in lipid-based edible coatings are neutral lipids, fatty acids, waxes, and resins (Hall 2012; Raghav et al. 2016; Hassan et al. 2018). Coatings derived from paraffin are used to preserve cheese, vegetables, and raw food (Hassan et al. 2018). Fruits and vegetables meant to be stored for a longer time are coated with formulations containing lipids incorporated with antifungal compounds and growth regulators (Hall 2012). Zambrano-Zaragoza et al. (2020) studied the effect of nano-edible coating based on beeswax lipid nanoparticles on strawberries for extending its quality by 21 days of storage at $4{ }^{\circ} \mathrm{C}$. Best results were obtained with $10 \mathrm{~g} \cdot \mathrm{L}^{-1}$ of beeswax solid nanoparticles dispersion giving the lowest weight loss $(6.1 \%)$, a decay index of $31 \%$, and loss of firmness of $34 \%$, being an excellent alternative to increase the shelf life of strawberries. Beeswax or stearic-palmitic acids $(1: 1)$ mixture was blended with gellan gum to form gellan/lipid composite films. The addition of lipids significantly improved the water vapor permeability but lowered the mechanical properties of the films. Beeswax was found to be a better alternative than the stearic-palmitic acids blend (Yang \& Paulson 2000).

\section{Aloe vera-based edible coatings}

Nowadays Aloe vera-based edible coating is emerging in the market demonstrating better results as compared to the traditional edible coatings and health benefits because it also acts as a medicine (Sharma et al. 2019). Aloe vera is reported to have 75 nutrients, sugars, anthraquinones, vitamins, minerals, salicylic acid, approximately 200 active compounds and amino acids that show medical properties (Dureja et al. 2005). For this reason, a gel-based on this plant was developed that can be used in the preservation of freshness of fruit freshness (Tripathi \& Dubey 2004; Misir et al. 2014).

This gel proves to be a harmless and safe alternative to sulfur dioxide, a synthetic preservative that is widely used all over the globe. The Aloe vera gel provides a protective layer against oxygen and moisture transmission from fresh fruits or vegetables and exhibits antibacterial, antiparasitic, antiviral (Misir et al. 2014), and antifungal properties due to which it is capable of inhibiting the microbial deterioration of food. Anthraquinones present in Aloe vera inhibit the solute transport in membranes of Staphylococcus aureus and Escherichia coli strains (Hamman 2008; Lone et al. 2009). It was also reported that Aloe vera inhibits the activity of foodborne pathogenic microbes, that is, Bacillus cereus, Salmonella typhimurium, Escherichia coli, Klebsiella pneumonia, etc. (Misir et al. 2014).

Emodin of Aloe vera is reported to be effective in inhibiting the activity of gram-positive bacteria (Cock 2008). The gel-based coatings have been proven to counteract moisture loss and retain firmness also, facilitating in maintaining the respiratory rate. It also controls fruit ripening, the maturation rate of vegetables, delay oxidative browning, and microbial growth (Castillo et al. 2010). Aloe-veragel-coated fruits do not depict a distinct taste and flavor and possess no harm to consumers (Misir et al. 2014). This gel blended with gaur gum for the preservation of Indian jujube (Ziziphus mauritiana Lamk) delayed the ripening process, a significant reduction in physiological weight loss, and visual 
quality retained for a longer period of time, hence, extending shelf life (Mani et al. 2018).

\section{Purees of fruits and vegetable-based edible coatings}

The formulation of edible coatings using fruit purees was reported first time in 1996 (McHugh et al. 1996). Fruit purees can be intermixed with biopolymers and active compounds to enhance the shelf life of perishable foods (Galus et al. 2020). One of the studies concluded that the shelf life of minimally processed fresh produces, such as pumpkin, carrot, persimmon, etc., can be extended using papaya puree as an edible coating. The papaya-puree-based edible coating can be added into minimally processed papaya to increase its nutritional values (Rangel-Marrón et al. 2019). The application of edible coatings formulated by blending alginate and acerola puree on acerola fruits showed a decrease in weight loss, ascorbic acid, ripening rate, and the decaying process, hence, extending the shelf life of acerola fruits (Azeredo et al. 2012). Papaya purees can be attained from fruit-processing wastes (Otoni et al. 2014). The composite coating of mango puree, gaur gum, sesame protein, and calcium chloride has been proved to enhance the shelf life of fresh-cut mango. The application of the mentioned coating on freshcut mangoes showed a decline in degradation of ascorbic acid, total phenolics content, and carotenoids level in the sample and was helpful in maintaining the firmness, total soluble solids, and sensory attributes of mango (Sharma et al. 2019).

\section{Composite films and coatings}

Composite edible coatings are a combination of protein/polysaccharide and lipid providing combined advantages. The water-soluble polymers (hydrocolloids) and lipid-based composite films provide the great water vapor barrier property of lipids and good oxygen and carbon dioxide barrier properties of carbohydrates. Bioactive compounds can be incorporated into composite films and coatings to improve their functionality (Sharma et al. 2019). Polysaccharides and proteins exhibit great mechanical and structural properties but lack good moisture barrier properties that can be overcome by blending lipids with them. The main reason behind the applicability of composite films and coatings is to aggregate the advantages provided by carbohydrates, proteins, and lipids into a single resultant coating or film; in addition to that, aggregating also helps in minimizing the loss of each component (Yousuf et al. 2018).

\section{Nanotechnology-based edible coatings}

Nanotechnology aids in the postharvest preservation of fresh produce. The nanosized zinc oxide, silicon, and calcium carbonate were used to enhance the shelf life of fresh produce and reduce the decay rate (Jianglian \& Shaoying 2013). The exercise of nanotechnology approaches such as the delivery of active or antimicrobial compounds using encapsulation methods has the potential to confront the issue of microbial-caused decay of fruits and vegetables; hence, it aids in maintaining the food quality attributes (Dhital et al. 2018; Jafarzadeh et al. 2021). Emulsification is a process to deliver advantageous compounds to a liquid solution. This approach is employed to make nano-emulsified edible coatings to convey active compounds onto the fresh produce via edible coatings. The application of citral-based nano-emulsified edible coating onto fresh-cut melons has proved to exhibit antimicrobial properties and extended the shelf life of the product (ArnonRips et al. 2019).

The implementation of the nanoencapsulation approach by incorporating curcumin and limonene into liposomes has proved to prolong the shelf life of strawberries, whereas the application of limonene liposomes has been found to have significant control over fungal decay and maintain total phenolic content (Dhital et al. 2017). The application of edible coating enriched with limonene liposomes on strawberries demonstrated positive results by extending the shelf life and reducing the respiration rate of food products (Dhital et al. 2018). The employment of solid-lipid nanoparticles with xanthan gum edible coating to preserve tomatoes exhibited positive results to the overall quality parameter of tomatoes (Miranda-Linares et al. 2018). The use of chitosan incorporated with a nanosilicon dioxide coating has proved to be an effective alternative to preserve the food quality attributes. The chitosan with nanosilicon dioxide onto jujube fruit has shown a positive impact in aspects of quality and shelf life (Yu et al. 2012). 


\section{Incorporation of antimicrobial and essential oils into edible coatings}

The concentration of phenolic compounds preventing microbial-caused decay is high in spices and herbs (thyme, rosemary, oregano, sage). Essential oils (EOs) are majorly recovered from herbs and spices that have high antioxidant properties; therefore, EOs can be used as natural antioxidants as well as provide antimicrobial protection. Active compounds can be extracted from byproducts of plants - pomegranate peel, olive leaves, etc. (Ganiari et al. 2017). Essential oils extracted from spices are commonly used as natural preservatives (Ju et al. 2019).

In the food industry, EOs are commonly used to provide flavor. Along with it, they obtain antioxidant and antimicrobial functional properties. EOs from bergamot, cinnamon, coriander, clove, eucalyptus, lemon, oregano, rosemary, sage, thyme, and tea tree are commonly used to develop edible coatings/films and provide promising antioxidant, antibacterial, and antifungal properties (Sánchez-González et al. 2011a, b). Carvacrol, thymol, and eugenol are the main components present in basil and thyme oils, which exhibit antioxidant properties (Lee et al. 2005). The EOs of oregano (Origanum vulgare L.) exhibit antibacterial properties as it deteriorates Staphylococcus aureus by altering the morphology of its cell surface, which results in loss of cytoplasmic material (de Souza et al. 2010). Oregano EOs repress the synthesis of staphylococcal enterotoxins (de Souza et al. 2010). The EOs also affect the mitochondrial membrane of bacteria (Rasooli et al. 2006). Terpenoid and phenolic compounds are the major components that exhibit antioxidant properties in essential oils. They are extensively used to preserve food (Sánchez-González et al. 2011a, b).

The EOs of tee tree were used as natural antioxidants in food, for example in preserving raspberries (Chanjirakul et al. 2006). The EOs of clove, lemon, eucalyptus, tea tree, roomer, and melissa were used in leafy vegetable produces (Ponce et al. 2004) and as factors preserving color, texture, and firmness, in fruits due to reduced water loss and lower respiration rate (Sánchez-González et al. 2011a). Commercially available oranges coated with Lippia scaberrima oil resulted in a reduction in weight loss (du Plooy et al. 2009).
The table grapes covered with an edible coating of HPC/chitosan enriched with bergamot oil resulted in a reduction in weight loss (Sánchez-González et al. 2011a). This coating reduced respiration rate in grapes (Sánchez-González et al. 2011a), apples, and melons (Raybaudi-Massilia et al. 2008). Various studies of these authors have shown that the incorporation of EOs into edible coating causes less consumption of oxygen and reduction in carbon dioxide production; the main reason behind this is the lipophilic nature of EO.

\section{Functional edible coatings}

Edible coatings are used as the vehicle for the incorporation of bioactive compounds such as antioxidants, probiotics, antimicrobials, and EOs for the improvement of food quality and the creation of functional foods. Bioactive components are present in food in minuscule quantities, and incorporation of these components into a product increases its nutritional value (Tajkarimi et al. 2010; QuirósSauceda et al. 2014). Incorporation of $\mathrm{N}$-acetylcysteine and glutathione into edible coatings was found to be effective in preventing browning reactions in fresh-cut pears for a period of 2 weeks without any textural damage (Song et al. 2011). No significant reduction in the number of viable organisms was observed during storage at $5{ }^{\circ} \mathrm{C}$ of strawberries coated with encapsulated Lactobacillus acidophilus and Bifidobacterium lactis in calcium alginate and $2 \%$ (w/v) solution. Some researchers have used edible coatings to add flavors to food products. Laohakunjit and Kerdchoechuen (2007) incorporated 25\% natural pandan leaf extract into $30 \%$ sorbitol-plasticized rice starch for coating of nonaromatic milled rice, resulting in produce with a smell similar to aromatic rice. Another approach is by adding flavor precursors in the coating formulations, which, when coming in contact with the food, may react with food components and produce flavoring compounds. An increase in the concentration of aroma compounds was observed when alginate calcium coatings using linoleic acid and isoleucine was applied on apple wedges (Olivas et al. 2012).

\section{Problems associated with edible coatings}

Even though edible coatings have been regarded as means of extending the shelf life of fruits and vegetables, still their commercialization faces many challenges. 
The effect of these coatings on sensory properties sometimes affects consumer acceptance. The incorporation of different herbs, spices, antimicrobials, and antioxidants could impart undesirable flavors to the commodities. Criteria for the selection of edible coating are based on respiration and transpiration rates of food and the storage conditions. Since fruits and vegetables differ in respiration rate, gas diffusion, and skin resistance, coating developed for one commodity may not be suitable for another. The thickness of the coating and method of application affect the permeability of pores, thus influencing transport-related properties. Refined mineral oil-based coatings result in anaerobic conditions, causing fruit injury (Moalemiyan et al. 2012). The anaerobic respiration results in fermentation and development of off-flavor detrimental to the sensory quality of the commodity. The application of essential oils in higher concentrations as antimicrobials in edible coatings may adversely affect the aroma of freshcut fruits. Azarakhsh et al. (2012) reported that the use of lemongrass oil in alginate-based coating for fresh-cut pineapple decreased the sensory score even when used at a low concentration. Antibrowning agents such as $\mathrm{N}$-acetylcysteine and glutathione, when used in higher concentrations, may result in unpleasant odors (İyidoğan \& Bayındırl1 2004). Therefore, minimizing the detrimental changes in sensory attributes can be a potential area of research that can be explored.

\section{Market trend and environmental impact}

The quality of living standard is increasing along with the significant demand for fruits and vegetables (Maringgal et al. 2020). The rise in health awareness among people leads to the elevated demand for fruits and vegetables rapidly due to their nutritional value. Fruits and vegetables comprise various nutrients, phenolic compounds, and antioxidants that aid in preventing many deadly diseases (Hassan et al. 2018). The main problem is connected with delivering fresh fruits and vegetables to the plate of consumers due to their perishable nature and high risk of postharvest losses in view of poor handling practices, ripening rate, and microbial contamination. Consumers demand fresh produce and judge that on the basis of visual attributes (Maringgal et al. 2020). The preservation of fruits and vegetables is a worldwide challenge; therefore, edible coatings made from natural sources are influential techniques used to overcome this trouble to some extent. Edible coatings are consumer-friendly as well as eco-friendly. Herbal edible coatings such as Aloe vera (Tripathi \& Dubey 2004; Misir et al. 2014) provide health benefits and act as nutraceuticals (Raghav et al. 2016) along with the preservation of fresh produce (Maringgal et al. 2020).

\section{CONCLUSION}

This review assembles up-to-date information about edible coatings and their application to preserve fruits and vegetables. Edible coatings support retaining the nutritional and sensory attributes of food products. The addition of natural antimicrobial and active ingredients into the coating formulation helps in preservation by exhibiting various properties (antibacterial, antifungal), which results in improved physical and chemical aspects of fruits and vegetables. The present study also discusses the use of edible matrix (carbohydrate/protein/composite/lipid) and its significant effects on the quality of fruits and vegetables. The review indicates that the application of composite-edible coating overcomes the drawback of raw material and delivers significant results. Consumers can choose fresh produce with high nutritional value instead of stale products in the market; therefore, the preservation of semiperishable produces such as fruits and vegetables has become a center of attraction for food industries. The edible coatings from natural sources (carbohydrates, proteins, and lipids) have come up with convenient results. Edible coatings can act as vehicles to carry nutraceutical components to provide additional health benefits to consumers. The herb-based edible coating also engages the researchers' curiosities and acceptance by consumers. The exploration of a suitable edible coating with respect to the food product is a vital factor that needs to be considered. 


\begin{tabular}{|c|c|c|c|c|c|c|c|c|c|c|}
\hline 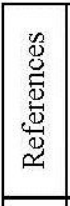 & 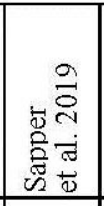 & 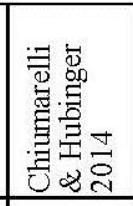 & 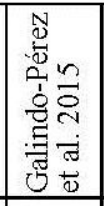 & 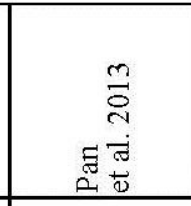 & 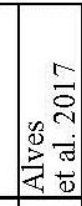 & 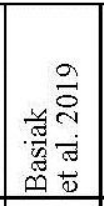 & 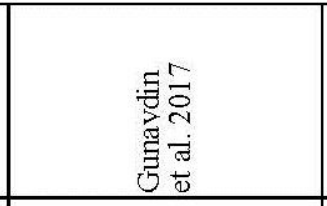 & 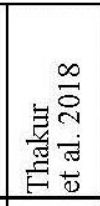 & 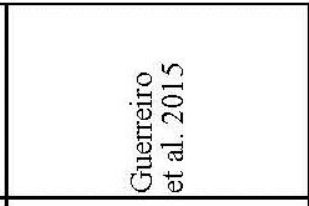 & 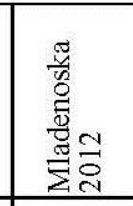 \\
\hline 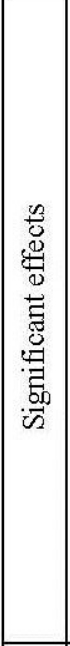 & 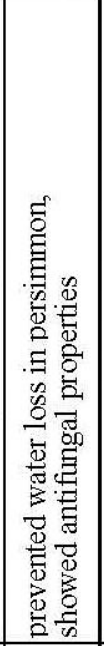 & 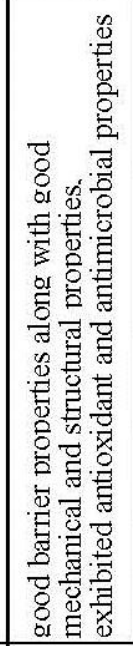 & 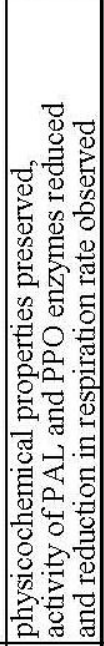 & 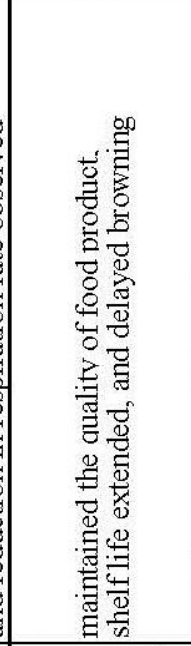 & 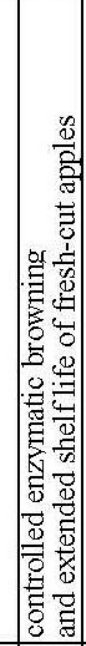 & 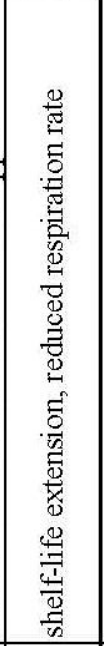 & 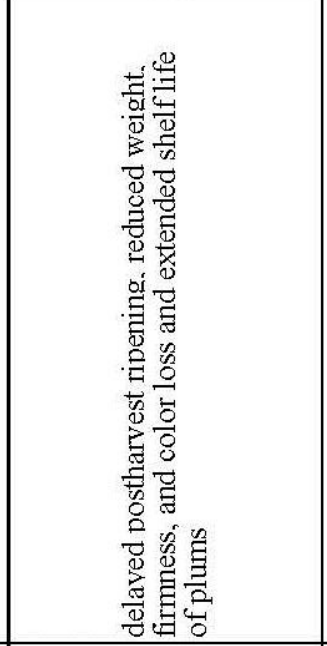 & 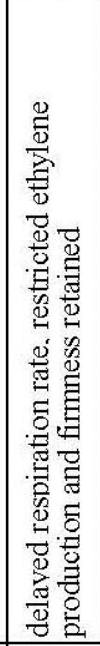 & 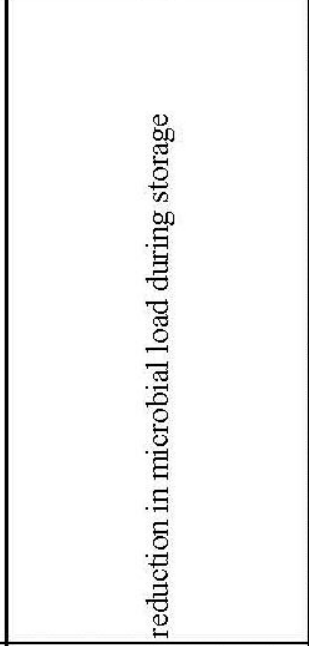 & 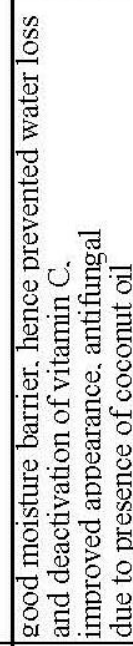 \\
\hline 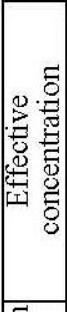 & 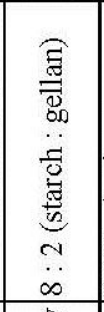 & 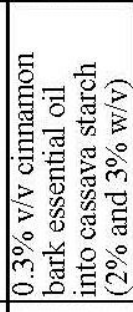 & ' & 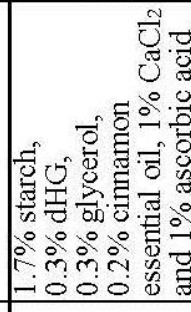 & 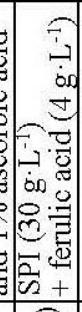 & 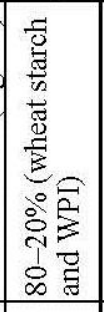 & 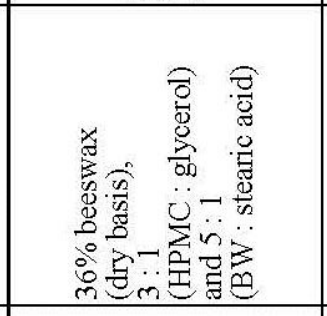 & ' & 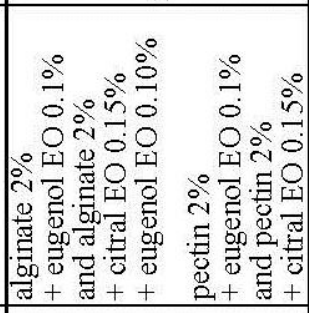 & 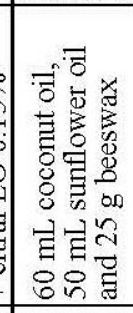 \\
\hline 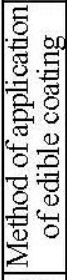 & 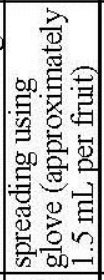 & 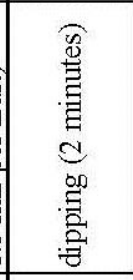 & . & 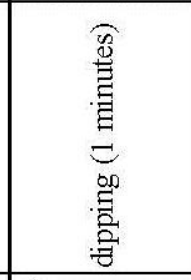 & 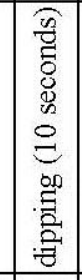 & 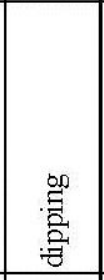 & 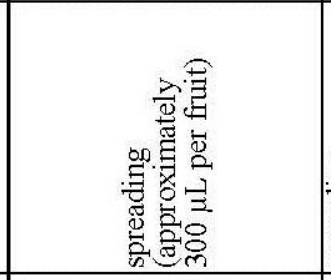 & 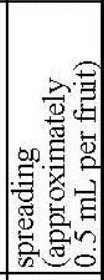 & 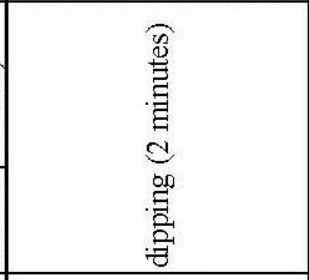 & 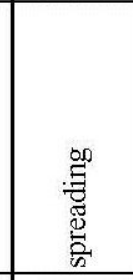 \\
\hline 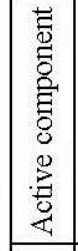 & 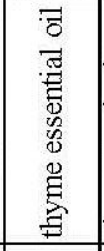 & 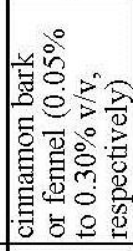 & 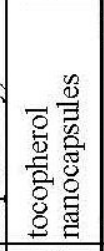 & 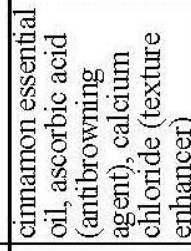 & : & ' & ' & ' & 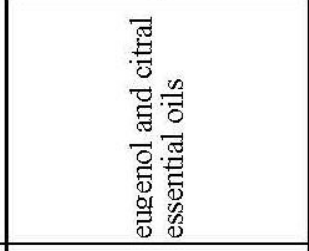 & 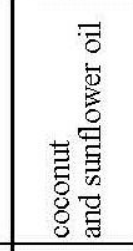 \\
\hline 兽 & 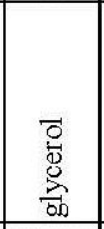 & $\begin{array}{l}\overrightarrow{0} \\
\text { d. } \\
\frac{2}{20} \\
0\end{array}$ & 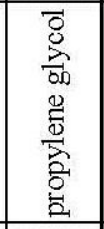 & 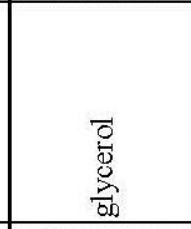 & 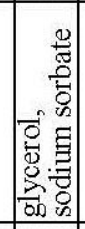 & 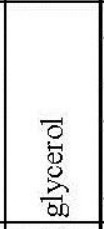 & 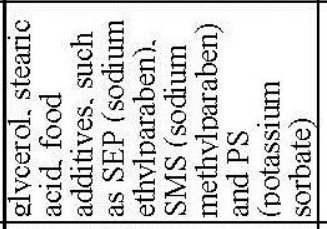 & 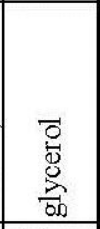 & & ' \\
\hline 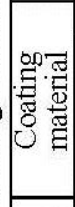 & 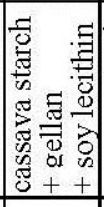 & 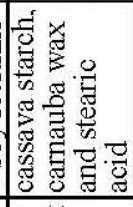 & 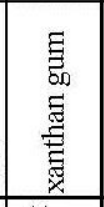 & 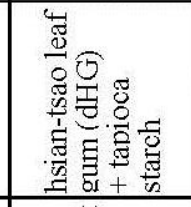 & 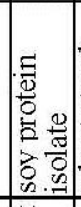 & 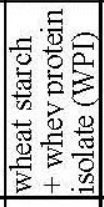 & 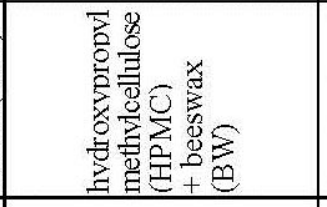 & 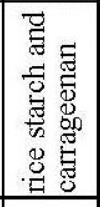 & 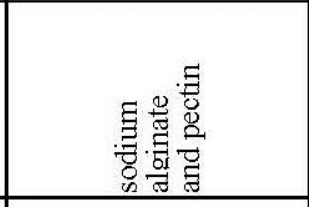 & 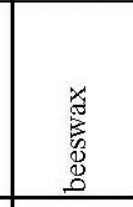 \\
\hline 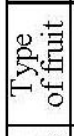 & 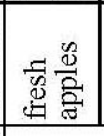 & 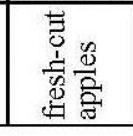 & 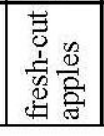 & 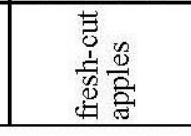 & 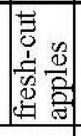 & 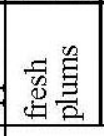 & 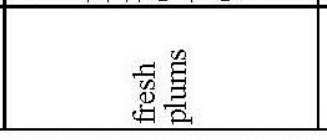 & 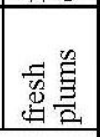 & 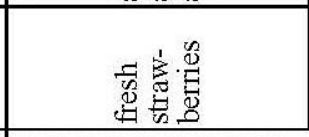 & 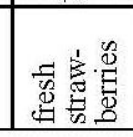 \\
\hline 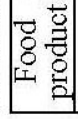 & & & 离 & & & & 悬 & & 窝. & \\
\hline
\end{tabular}




\begin{tabular}{|c|c|c|c|c|c|c|c|c|c|c|c|}
\hline हूँ & 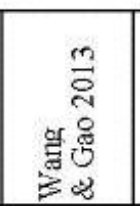 & 水 & 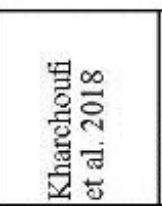 & 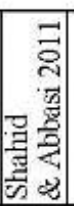 & 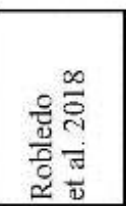 & 这 & 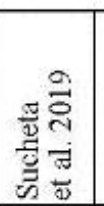 & $\frac{\stackrel{9}{5}}{\frac{\pi}{a}}$ & 월 & $\begin{array}{r}\frac{0}{0} \\
=\frac{1}{a}\end{array}$ & : \\
\hline 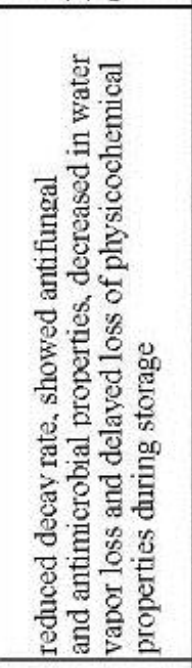 & 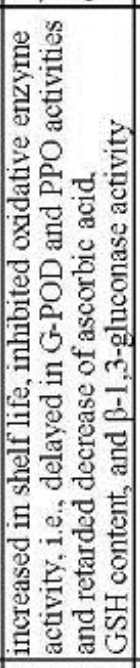 & 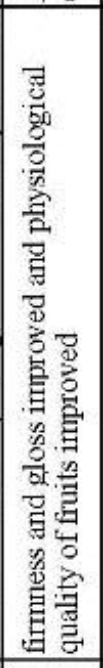 & 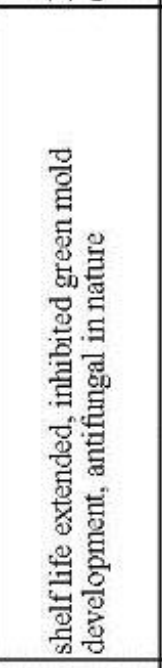 & 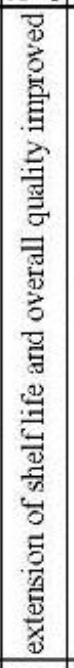 & 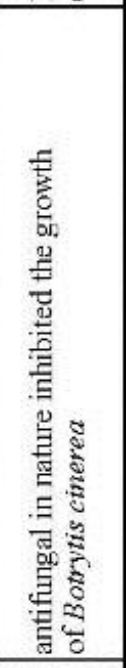 & 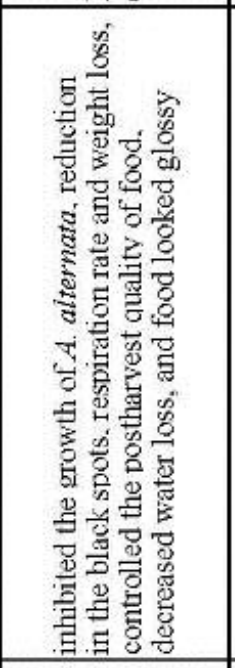 & 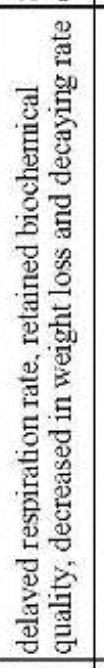 & 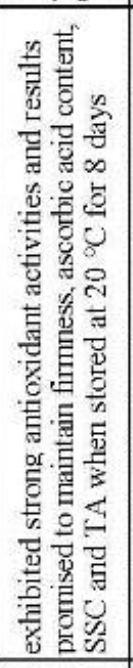 & 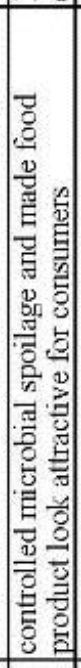 & 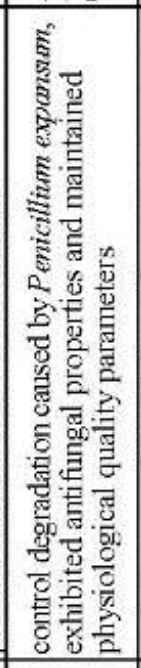 & 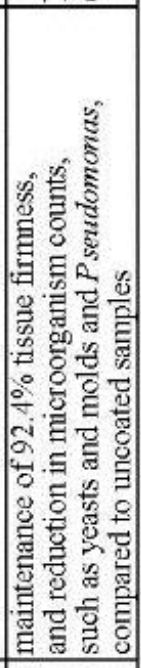 \\
\hline 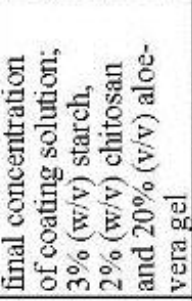 & 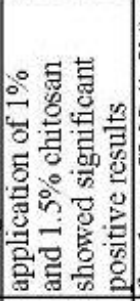 & 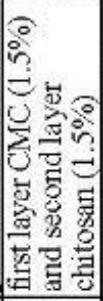 & 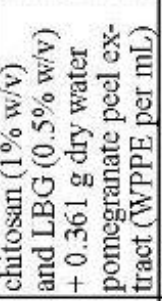 & 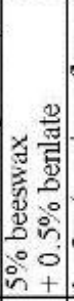 & 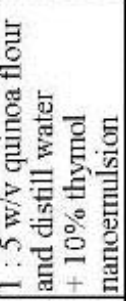 & ' & & 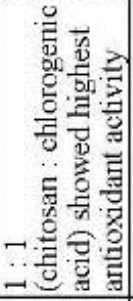 & , & 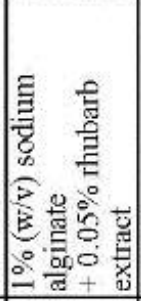 & 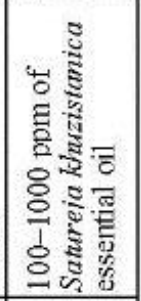 \\
\hline 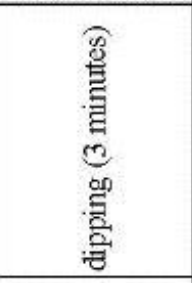 & 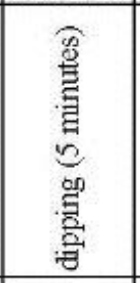 & 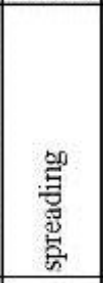 & & ' & 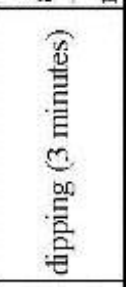 & 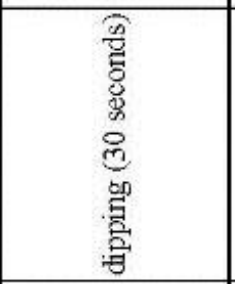 & 喜 & ' & 点 & $\frac{\text { है }}{\frac{5}{2}}$ & \\
\hline 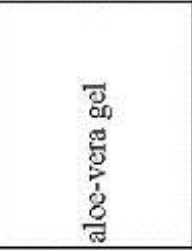 & ' & ' & 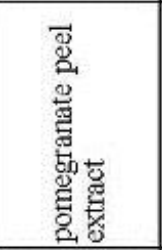 & ' & 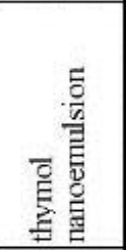 & ' & & ' & 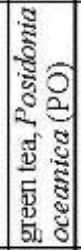 & 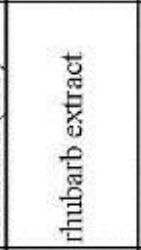 & 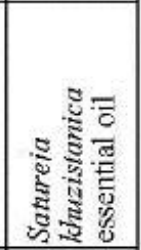 \\
\hline 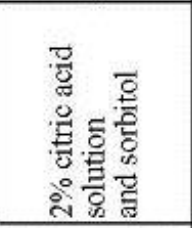 & 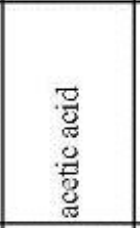 & 总 & ' & 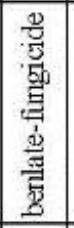 & ' & 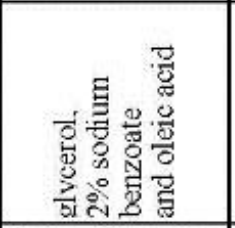 & 总 & 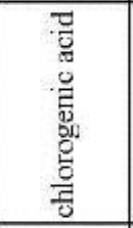 & ' & . & \\
\hline 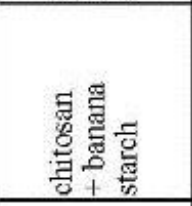 & 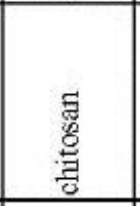 & 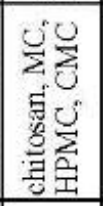 & 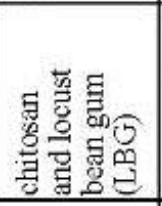 & 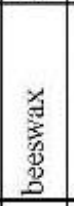 & 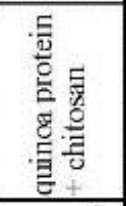 & 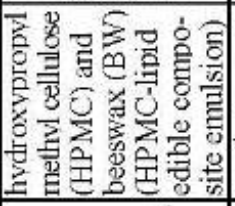 & 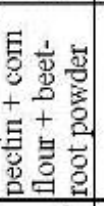 & 蕓 & ' & 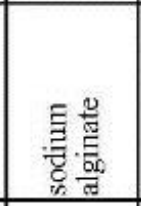 & 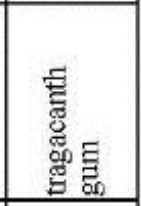 \\
\hline 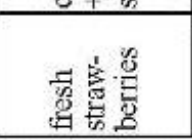 & 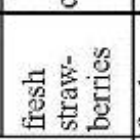 & 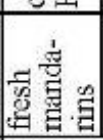 & $\begin{array}{l}\text { 荡青 } \\
\text { 晋 }\end{array}$ & 点: & 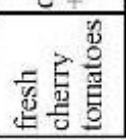 & 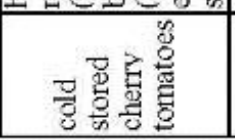 & 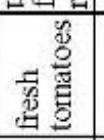 & 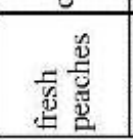 & 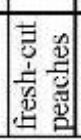 & 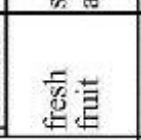 & 苞 \\
\hline & & & $\stackrel{2}{\mathcal{D}_{0}^{\circ}}$ & & \multicolumn{3}{|c|}{ 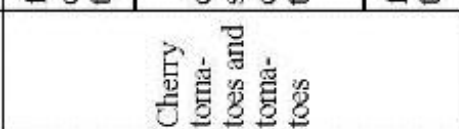 } & \multicolumn{3}{|c|}{$\begin{array}{l}3 \\
\frac{3}{4} \\
0 \\
2 \\
2\end{array}$} & 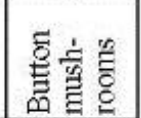 \\
\hline
\end{tabular}




\section{REFERENCES}

Alves M.M., Gonçalves M.P., Rocha C.M.R. 2017. Effect of ferulic acid on the performance of soy protein isolate-based edible coatings applied to freshcut apples. LWT - Food Science and Technology 80: 409-415. DOI: 10.1016/j.lwt.2017.03.013.

Andrade R.D., Skurtys O., Osorio F.A. 2012. Atomizing spray systems for application of edible coatings. Comprehensive Reviews in Food Science and Food Safety 11(3): 323-337. DOI: 10.1111/j.1541-4337.2012.00186.x.

Arnon H., Granit R., Porat R., Poverenov E. 2015. Development of polysaccharides-based edible coatings for citrus fruits: A layer-by-layer approach. Food Chemistry 166: 465-472. DOI: 10.1016/j.foodchem.2014.06.061.

Arnon-Rips H., Porat R., Poverenov E. 2019. Enhancement of agricultural produce quality and storability using citral-based edible coatings; the valuable effect of nano-emulsification in a solid-state delivery on fresh-cut melons model. Food Chemistry 277: 205-212. DOI: 10.1016/j.foodchem.2018.10.117.

Azarakhsh N., Osman A., Ghazali H.M., Tan C.P., Mohd Adzahan N. 2012. Optimization of alginate and gellan-based edible coating formulations for fresh-cut pineapples. International Food Research Journal 19(1): 279-285.

Azeredo H.M.C., Miranda K.W.E., Ribeiro H.L., Rosa M.F., Nascimento D.M. 2012. Nanoreinforced alginate-acerola puree coatings on acerola fruits. Journal of Food Engineering 113(4): 505-510. DOI: 10.1016/j.jfoodeng.2012.08.006.

Basiak E., Linke M., Debeaufort F., Lenart A., Geyer M. 2019 Dynamic behaviour of starch-based coatings on fruit surfaces. Postharvest Biology and Technology 147: 166-173. DOI: 10.1016/j.postharvbio.2018.09.020.

Calderón-Castro A., Vega-García M.O., de Jesús Zazueta-Morales J., Fitch-Vargas P.R., CarrilloLópez A., Gutiérrez-Dorado R. et al. 2018. Effect of extrusion process on the functional properties of high amylose corn starch edible films and its application in mango (Mangifera indica L.) cv. Tommy Atkins. Journal of Food Science and Technology 55(3): 905-914. DOI: 10.1007/s13197-017-2997-6.

Castillo S., Navarro D., Zapata P.J., Guillén F., Valero D., Serrano M., Martínez-Romero D. 2010. Antifungal efficacy of Aloe vera in vitro and its use as a preharvest treatment to maintain postharvest table grape quality. Postharvest Biology and Technology 57(3): 183-188. DOI: 10.1016/j.postharvbio.2010.04.006.

Cazón P., Velazquez G., Ramírez J.A., Vázquez M. 2017. Polysaccharide-based films and coatings for food packaging: A review. Food Hydrocolloids 68: 136148. DOI: 10.1016/j.foodhyd.2016.09.009.
Chanjirakul K., Wang S.Y., Wang C.Y., Siriphanich J. 2006. Effect of natural volatile compounds on antioxidant capacity and antioxidant enzymes in raspberries. Postharvest Biology and Technology 40(2): 106-115. DOI: 10.1016/j.postharvbio.2006.01.004.

Chen Q., Roether J.A., Boccaccini A.R. 2008. Tissue engineering scaffolds from bioactive glass and composite materials. In: Ashammakhi N., Reis R., Chiellini F. (Eds.), Topics in Tissue Engineering 4. Oulu University, Finland, 27 p.

Chiumarelli M., Hubinger M.D. 2014. Evaluation of edible films and coatings formulated with cassava starch, glycerol, carnauba wax and stearic acid. Food Hydrocolloids 38: 20-27. DOI: 10.1016/j.foodhyd.2013.11.013.

Cock I. 2008. Antimicrobial activity of Aloe barbadensis Miller leaf gel components. Internet Journal of Microbiology 4(2), 8 p. DOI: 10.1016/j.foodhyd.2013.11.013.

Corbo M.R., Campaniello D., Speranza B., Bevilacqua A., Sinigaglia M. 2015. Non-conventional tools to preserve and prolong the quality of minimally-processed fruits and vegetables. Coatings 5(4): 931-961. DOI: 10.3390/coatings5040931.

Cortez-Vega W.R., Pizato S., de Souza J.T.A., Prentice C. 2014. Using edible coatings from Whitemouth croaker (Micropogonias furnieri) protein isolate and organo-clay nanocomposite for improve the conservation properties of fresh-cut 'Formosa' papaya. Innovative Food Science and Emerging Technologies 22: 197-202. DOI: 10.1016/j.ifset.2013.12.007.

Dhall R.K. 2013. Advances in edible coatings for fresh fruits and vegetables: a review. Critical Reviews in Food Science and Nutrition 53(5): 435-450. DOI: 10.1080/10408398.2010.541568.

Dhital R., Joshi P., Becerra-Mora N., Umagiliyage A., Chai T., Kohli P., Choudhary R. 2017. Integrity of edible nano-coatings and its effects on quality of strawberries subjected to simulated in-transit vibrations. LWT - Food Science and Technology 80: 257-264. DOI: 10.1016/j.lwt.2017.02.033.

Dhital R., Becerra-Mora N., Watson D.G., Kohli P., Choudhary R. 2018. Efficacy of limonene nano coatings on post-harvest shelf life of strawberries. LWT - Food Science and Technology 97: 124-134. DOI: 10.1016/j.lwt.2018.06.038.

Dureja H., Kaushik D., Kumar N., Sardana S. 2005. Aloe vera. Indian Pharmacist 38 (4): 9-13.

Embuscado M.E., Huber K.C. 2009. Edible Films and Coatings for Food Applications. Springer, USA, 416 p. DOI: 10.1007/978-0-387-92824-1.

Fagundes C., Palou L., Monteiro A.R., Pérez-Gago M.B. 2015. Hydroxypropyl methylcellulose-beeswax edible coatings formulated with antifungal food additives to reduce alternaria black spot and maintain postharvest quality of cold-stored cherry tomatoes. Scientia Horticulturae 193: 249-257. DOI: 10.1016/j.scienta.2015.07.027. 
Fakhouri F.M., Costa D., Yamashita F., Martelli S.M., Jesus R.C., Alganer K. et al. 2013. Comparative study of processing methods for starch/gelatin films. Carbohydrate Polymers 95(2): 681-689. DOI: 10.1016/j.carbpol.2013.03.027.

Galindo-Pérez M.J., Quintanar-Guerrero D., MercadoSilva E., Real-Sandoval S.A., Zambrano-Zaragoza M.L. 2015. The effects of tocopherol nanocapsules/xanthan gum coatings on the preservation of fresh-cut apples: Evaluation of phenol metabolism. Food and Bioprocess Technology 8(8): 1791-1799. DOI: $10.1007 / \mathrm{s} 11947-015-1523-y$.

Galus S., Arik Kibar E.A., Gniewosz M., Kraśniewska K. 2020. Novel materials in the preparation of edible films and coatings - A review. Coatings 10(7); 674; 14 p. DOI: 10.3390/coatings10070674.

Ganiari S., Choulitoudi E., Oreopoulou V. 2017. Edible and active films and coatings as carriers of natural antioxidants for lipid food. Trends in Food Science and Technology 68: 70-82. DOI: 10.1016/j.tifs.2017.08.009.

Gesford P. 2002. Challenges in panning. Manufacturing Confectioner 82(11): 43-50. Global Source for Chocolate, Confectionery and Biscuit Information. Princeton, USA.

Guerreiro A.C., Gago C.M.L., Faleiro M.L., Miguel M.G.C., Antunes M.D.C. 2015. The use of polysaccharide-based edible coatings enriched with essential oils to improve shelf-life of strawberries. Postharvest Biology and Technology 110: 51-60. DOI: 10.1016/j.postharvbio.2015.06.019.

Gunaydin S., Karaca H., Palou L., de la Fuente B., PérezGago M.B. 2017. Effect of hydroxypropyl methylcellulose-beeswax composite edible coatings formulated with or without antifungal agents on physicochemical properties of plums during cold storage. Journal of Food Quality 2017; 8573549; 9 p. DOI: $10.1155 / 2017 / 8573549$.

Hall D.J. 2012. Edible coatings from lipids, waxes, and resins. In: Baldwin E.A., Hagenmaier R., Bai J. (Eds.), Edible Coatings and Films to Improve Food Quality, 2nd ed. CRC Press, USA, pp. 79-101. DOI: $10.1201 / \mathrm{b} 11082$.

Hamman J.H. 2008. Composition and applications of Aloe vera leaf gel. Molecules 13(8): 1599-1616. DOI: $10.3390 /$ molecules 13081599 .

Hassan B., Chatha S.A.S., Hussain A.I., Zia K.M., Akhtar N. 2018. Recent advances on polysaccharides, lipids and protein based edible films and coatings: A review. International Journal of Biological Macromolecules 109: 1095-1107. DOI: 10.1016/j.ijbiomac.2017.11.097.
İyidoğan N.F., Bayındırlı A. 2004. Effect of L-cysteine, kojic acid and 4-hexylresorcinol combination on inhibition of enzymatic browning in Amasya apple juice. Journal of Food Engineering 62(3): 299-304. DOI: 10.1016/s0260-8774(03)00243-7.

Jafarzadeh S., Nafchi A.M., Salehabadi A., Oladzad-abbasabadi N., Jafari S.M. 2021. Application of bionanocomposite films and edible coatings for extending the shelf life of fresh fruits and vegetables. Advances in Colloid and Interface Science 291; 102405; 13 p. DOI: 10.1016/j.cis.2021.102405.

Jemilakshmi T.V., Rakshana L., Krishna Priya S.J., Aishwarya B., Anithaee C. 2020. Postharvest quality enhancement of fruits and vegetables using edible coatings: A review. Journal of Critical Reviews 7(7): 786-790. DOI: 10.31838/jcr.07.07.143.

Jensen A., Lim L.-T., Barbut S., Marcone M. 2015. Development and characterization of soy protein films incorporated with cellulose fibers using a hot surface casting technique. LWT - Food Science and Technology 60(1): 162-170. DOI: 10.1016/j.lwt.2014.09.027.

Jianglian D., Shaoying Z. 2013. Application of chitosan based coating in fruit and vegetable preservation: A review. Journal of Food Processing and Technology 4(5); 1000227; 4 p. DOI: 10.4172/2157-7110.1000227.

Jiao W., Shu C., Li X., Cao J., Fan X., Jiang W. 2019. Preparation of a chitosan-chlorogenic acid conjugate and its application as edible coating in postharvest preservation of peach fruit. Postharvest Biology and Technology 154: 129-136. DOI: 10.1016/j.postharvbio.2019.05.003.

Ju J., Xie Y., Guo Y., Cheng Y., Qian H., Yao W. 2019. Application of edible coating with essential oil in food preservation. Critical Reviews in Food Science and Nutrition 59(15): 2467-2480. DOI: 10.1080/10408398.2018.1456402.

Kang H.-J., Kim S.-J., You Y.-S., Lacroix M., Han J. 2013. Inhibitory effect of soy protein coating formulations on walnut (Juglans regia L.) kernels against lipid oxidation. LWT - Food Science and Technology 51(1): 393-396. DOI: 10.1016/j.lwt.2012.10.019.

Karaca H., Pérez-Gago M.B., Taberner V., Palou L. 2014. Evaluating food additives as antifungal agents against Monilinia fructicola in vitro and in hydroxypropyl methylcellulose-lipid composite edible coatings for plums. International Journal of Food Microbiology 179: 72-79. DOI: 10.1016/j.ijfoodmicro.2014.03.027. Kharchoufi S., Parafati L., Licciardello F., Muratore G., Hamdi M., Cirvilleri G., Restuccia C. 2018. Edible coatings incorporating pomegranate peel extract and biocontrol yeast to reduce Penicillium digitatum postharvest decay of oranges. Food Microbiology 74: 107-112. DOI: 10.1016/j.fm.2018.03.011. 
Krochta J.M. 2002. Proteins as raw materials for films and coatings: definitions, current status, and opportunities. In: Gennadios A. (Ed.), Protein-based Films and Coatings. CRC Press, USA, pp. 1-40. DOI: $10.1201 / 9781420031980$.

Laohakunjit N., Kerdchoechuen O. 2007. Aroma enrichment and the change during storage of non-aromatic milled rice coated with extracted natural flavor. Food Chemistry 101(1): 339-344. DOI: 10.1016/j.foodchem.2005.12.055.

Lee S.-J., Umano K., Shibamoto T., Lee K.-G. 2005. Identification of volatile components in basil (Ocimum basilicum L.) and thyme leaves (Thymus vulgaris L.) and their antioxidant properties. Food Chemistry 91(1): 131-137. DOI: 10.1016/j.foodchem.2004.05.056.

Li X.-y., Du X.-1., Liu Y., Tong L.-j., Wang Q., Li J.-1. 2019. Rhubarb extract incorporated into an alginate-based edible coating for peach preservation. Scientia Horticulturae 257; 108685; 7 p. DOI: 10.1016/j.scienta.2019.108685.

Lin D., Zhao Y. 2007. Innovations in the development and application of edible coatings for fresh and minimally processed fruits and vegetables. Comprehensive Reviews in Food Science and Food Safety 6(3): 60-75. DOI: 10.1111/j.1541-4337.2007.00018.x.

Lone M.A., Malviya D., Mishra P., Dubey A., Saxena R.C. 2009. Antiinflammatory and antimicrobial activity of anthraquinone isolated from Aloe vera (Liliaceae). Asian Journal of Chemistry 21(3): 1807-1811.

Luchese C.L., Brum L.F.W., Piovesana A., Caetano K., Flôres S.H. 2017. Bioactive compounds incorporation into the production of functional biodegradable films - A review. Polymers from Renewable Resources 8(4): 151-176. DOI: $10.1177 / 204124791700800402$.

Mani A., Prasanna V.S.S.V., Halder S., Praveena J. 2018. Efficacy of edible coatings blended with aloe vera in retaining post-harvest quality and improving storage attributes in ber (Ziziphus mauritiana Lamk.). International Journal of Chemical Studies 6(6): 1727-1733.

Maringgal B., Hashim N., Tawakkal I.S.M.A., Mohamed M.T.M. 2020. Recent advance in edible coating and its effect on fresh/fresh-cut fruits quality. Trends in Food Science and Technology 96: 253-267. DOI: 10.1016/j.tifs.2019.12.024.

McHugh T.H., Huxsoll C.C., Krochta J.M. 1996. Permeability properties of fruit puree edible films. Journal of Food Science 61(1): 88-91. DOI: 10.1111/j.1365-2621.1996.tb14732.x.

Mehyar G.F., Al-Qadiri H.M., Swanson B.G. 2014. Edible coatings and retention of potassium sorbate on apples, tomatoes and cucumbers to improve antifungal activity during refrigerated storage. Journal of Food Processing and Preservation 38(1): 175182. DOI: 10.1111/j.1745-4549.2012.00762.x.

Miranda-Linares V., Escamilla-Rendón P., Del Real-López A., González-Reza R.M., Zambrano-Zaragoza M.L. 2018. Solid lipid nanoparticles based edible coating for saladette tomato preservation. Acta Horticulturae 1194: 305-312. DOI: 10.17660/actahortic.2018.1194.44.

Misir J., Brishti F.H., Hoque M.M. 2014. Aloe vera gel as a novel edible coating for fresh fruits: A review. American Journal of Food Science and Technology 2(3): 93-97. DOI: 10.12691/ajfst-2-3-3.

Mladenoska I. 2012. The potential application of novel beeswaxedible coatings containing coconut oil in the minimal processing of fruits. Advanced Technologies 1(2): 26-34.

Moalemiyan M., Ramaswamy H.S., Maftoonazad N. 2012. Pectin-based edible coating for shelf-life extension of Ataulfo mango. Journal of Food Process Engineering 35(4): 572-600. DOI: 10.1111/j.1745-4530.2010.00609.x.

Mohamed S.A.A., El-Sakhawy M., El-Sakhawy M.A.M. 2020. Polysaccharides, protein and lipid-based natural edible films in food packaging: A review. Carbohydrate Polymers 238; 116178; 14 p. DOI: 10.1016/j.carbpol.2020.116178.

Nasiri M., Barzegar M., Sahari M.A., Niakousari M. 2018. Application of tragacanth gum impregnated with Satureja khuzistanica essential oil as a natural coating for enhancement of postharvest quality and shelf life of button mushroom (Agaricus bisporus). International Journal of Biological Macromolecules 106: 218-226. DOI: 10.1016/j.ijbiomac.2017.08.003.

Olivas G.I., Maya I., Espino-Díaz M., Molina-Corral J., Olivas Dorantes C., Sepulveda D.R. 2012. Metabolization of linoleic acid and isoleucine for aroma production in fresh-cut 'Golden Delicious' apples using alginate coatings as the holding matrix. IFT Annual Meeting. Book of Abstracts; 275-13.

Otoni C.G., de Moura M.R., Aouada F.A., Camilloto G.P., Cruz R.S., Lorevice M.V. et al. 2014. Antimicrobial and physical-mechanical properties of pectin/papaya puree/cinnamaldehyde nanoemulsion edible composite films. Food Hydrocolloids 41: 188-194. DOI: 10.1016/j.foodhyd.2014.04.013.

Pan S.-Y., Chen C.-H., Lai L.-S. 2013. Effect of tapioca starch/decolorized hsian-tsao leaf gum-based active coatings on the qualities of fresh-cut apples. Food and Bioprocess Technology 6(8): 2059-2069. DOI: 10.1007/s11947-012-0907-5. 
Pandey P., Turton R., Joshi N., Hammerman E., Ergun J. 2006. Scale-up of a pan-coating process. AAPS PharmSciTech 7(4); 102; 8 p. DOI: 10.1208/pt0704102.

Pavlath A.E., Orts W. 2009. Edible films and coatings: Why, what, and how? In: Embuscado M.E., Huber K.C. (Eds.), Edible Films and Coatings for Food Applications. Springer, USA, pp. 1-23. DOI: 10.1007/978-0-387-92824-1_1.

Peressini D., Bravin B., Lapasin R., Rizzotti C., Sensidoni A. 2003. Starch-methylcellulose based edible films: rheological properties of film-forming dispersions. Journal of Food Engineering 59(1): 25-32. DOI: 10.1016/S0260-8774(02)00426-0.

Pinzon M.I., Sanchez L.T., Garcia O.R., Gutierrez R., Luna J.C., Villa C.C. 2020. Increasing shelf life of strawberries (Fragaria ssp) by using a banana starch-chitosan-Aloe vera gel composite edible coating. International Journal of Food Science and Technology 55(1): 92-98. DOI: 10.1111/ijfs.14254.

Piva G., Fracassetti D., Tirelli A., Mascheroni E., Musatti A., Inglese P. et al. 2017. Evaluation of the antioxidant/antimicrobial performance of Posidonia oceanica in comparison with three commercial natural extracts and as a treatment on freshcut peaches (Prunus persica Batsch). Postharvest Biology and Technology 124: 54-61. DOI: 10.1016/j.postharvbio.2016.10.001

du Plooy W., Regnier T., Combrinck S. 2009. Essential oil amended coatings as alternatives to synthetic fungicides in citrus postharvest management. Postharvest Biology and Technology 53(3): 117-122. DOI: 10.1016/j.postharvbio.2009.04.005.

Ponce A.G., del Valle C.E., Roura S.I. 2004. Natural essential oils as reducing agents of peroxidase activity in leafy vegetables. LWT - Food Science and Technology 37(2): 199-204. DOI: 10.1016/j.lwt.2003.07.005.

Quirós-Sauceda A.E., Ayala-Zavala J.F., Olivas G.I., González-Aguilar G.A. 2014. Edible coatings as encapsulating matrices for bioactive compounds: a review. Journal of Food Science and Technology 51(9): 1674-1685. DOI: 10.1007/s13197-013-1246-x.

Raghav P.K., Agarwal N., Saini M. 2016. Edible coating of fruits and vegetables: A review. International Journal of Scientific Research and Modern Education 1(1): 188-204.

Rangel-Marrón M., Mani-López E., Palou E., López-Malo A. 2019. Effects of alginate-glycerol-citric acid concentrations on selected physical, mechanical, and barrier properties of papaya puree-based edible films and coatings, as evaluated by response surface methodology. LWT - Food Science and Technology 101: 83-91. DOI: 10.1016/j.lwt.2018.11.005.
Rasooli I., Rezaei M.B., Allameh A. 2006. Growth inhibition and morphological alterations of Aspergillus niger by essential oils from Thymus eriocalyx and Thymus x-porlock. Food Control 17(5): 359-364. DOI: 10.1016/j.foodcont.2004.12.002.

Raybaudi-Massilia R.M., Mosqueda-Melgar J., MartínBelloso O. 2008. Edible alginate-based coating as carrier of antimicrobials to improve shelf-life and safety of fresh-cut melon. International Journal of Food Microbiology 121(3): 313-327. DOI: 10.1016/j.ijfoodmicro.2007.11.010.

Robledo N., Vera P., López L., Yazdani-Pedram M., Tapia C., Abugoch L. 2018. Thymol nanoemulsions incorporated in quinoa protein/chitosan edible films; antifungal effect in cherry tomatoes. Food Chemistry 246: 211-219. DOI: 10.1016/j.foodchem.2017.11.032.

Salehi F. 2020. Edible coating of fruits and vegetables using natural gums: A review. International Journal of Fruit Science 20(Supplement 2): 570-589. DOI: 10.1080/15538362.2020.1746730.

Sait H.H., Ma H.B. 2009. An experimental investigation of thin-film evaporation. Nanoscale and Microscale Thermophysical Engineering 13(4): 218-227. DOI: 10.1080/15567260903276973.

Sapper M., Chiralt A. 2018. Starch-based coatings for preservation of fruits and vegetables. Coatings 8(5); 152; 19 p. DOI: 10.3390/coatings8050152.

Sapper M., Palou L., Pérez-Gago M.B., Chiralt A. 2019. Antifungal starch-gellan edible coatings with thyme essential oil for the postharvest preservation of apple and persimmon. Coatings 9(5); 333; 15 p. DOI: 10.3390/coatings9050333.

Sánchez-González L., Pastor C., Vargas M., Chiralt A., González-Martínez C., Cháfer M. 2011a. Effect of hydroxypropylmethylcellulose and chitosan coatings with and without bergamot essential oil on quality and safety of cold-stored grapes. Postharvest Biology and Technology 60(1): 57-63. DOI: 10.1016/j.postharvbio.2010.11.004.

Sánchez-González L., Vargas M., González-Martínez C., Chiralt A., Cháfer M. 2011b. Use of essential oils in bioactive edible coatings. Food Engineering Reviews 3(1): 1-16. DOI: 10.1007/s12393-010-9031-3.

Senturk Parreidt T., Schmid M., Müller K. 2018. Effect of dipping and vacuum impregnation coating techniques with alginate based coating on physical quality parameters of cantaloupe melon. Journal of Food Science 83(4): 929-936. DOI: 10.1111/1750-3841.14091.

Shahid M.N., Abbasi N.A. 2011. Effect of bee wax coatings on physiological changes in fruits of sweet orange cv. "Blood Red". Sarhad Journal of Agriculture 27(3): 385-394. 
Sharma L., Saini C.S., Sharma H.K., Sandhu K.S. 2019. Biocomposite edible coatings based on cross linked-sesame protein and mango puree for the shelf life stability of fresh-cut mango fruit. Journal of Food Process Engineering 42(1); e12938; 9 p. DOI: 10.1111/jfpe.12938.

Siemann U. 2005. Solvent cast technology - a versatile tool for thin film production. Progress in Colloid and Polymer Science 130: 1-14. DOI: 10.1007/b107336.

Sothornvit R., Krochta J.M. 2005. Plasticizers in edible films and coatings. In: Han J.H. (Ed.), Innovations in Food Packaging. Food Science and Technology. Academic Press, pp. 403-433. DOI: 10.1016/b978-012311632-1/50055-3.

Song Y., Liu L., Shen H., You J., Luo Y. 2011. Effect of sodium alginate-based edible coating containing different anti-oxidants on quality and shelf life of refrigerated bream (Megalobrama amblycephala). Food Control 22(3-4): 608-615. DOI: 10.1016/j.foodcont.2010.10.012.

de Souza E.L., de Barros J.C., de Oliveira C.E.V., da Conceição M.L. 2010. Influence of Origanum vulgare L. essential oil on enterotoxin production, membrane permeability and surface characteristics of Staphylococcus aureus. International Journal of Food Microbiology 137(2-3): 308-311. DOI: 10.1016/j.ijfoodmicro.2009.11.025.

Sucheta, Chaturvedi K., Sharma N., Yadav S.K. 2019. Composite edible coatings from commercial pectin, corn flour and beetroot powder minimize post-harvest decay, reduces ripening and improves sensory liking of tomatoes. International Journal of Biological Macromolecules 133: 284-293. DOI: 10.1016/j.ijbiomac.2019.04.132.

Suhag R., Kumar N., Trajkovska Petkoska A., Upadhyay A. 2020. Film formation and deposition methods of edible coating on food products: A review. Food Research International 136; 109582; 16 p. DOI: 10.1016/j.foodres.2020.109582.

Tahir H.E., Xiaobo Z., Mahunu G.K., Arslan M., Abdalhai M., Zhihua L. 2019. Recent developments in gum edible coating applications for fruits and vegetables preservation: A review. Carbohydrate Polymers 224; 115141; 15 p. DOI: 10.1016/j.carbpol.2019.115141.

Tajkarimi M.M., Ibrahim S.A., Cliver D.O. 2010. Antimicrobial herb and spice compounds in food. Food Control 21(9): 1199-1218. DOI: 10.1016/j.foodcont.2010.02.003.

Thakur R., Pristijono P., Golding J.B., Stathopoulos C.E., Scarlett C.J., Bowyer M. et al. 2018. Development and application of rice starch based edible coating to improve the postharvest storage potential and quality of plum fruit (Prunus salicina). Scientia Horticulturae 237: 59-66. DOI: 10.1016/j.scienta.2018.04.005.

Tripathi P., Dubey N.K. 2004. Exploitation of natural products as an alternative strategy to control postharvest fungal rotting of fruit and vegetables. Postharvest Biology and Technology 32(3): 235-245. DOI: 10.1016/j.postharvbio.2003.11.005.

Valdés A., Ramos M., Beltrán A., Jiménez A., Garrigós M.C. 2017. State of the art of antimicrobial edible coatings for food packaging applications. Coatings 7(4); 56; 23 p. DOI: 10.3390/coatings7040056.

Valverde J.M., Valero D., Martínez-Romero D., Guillén F., Castillo S., Serrano M. 2005. Novel edible coating based on Aloe vera gel to maintain table grape quality and safety. Journal of Agricultural and Food Chemistry 53(20): 7807-7813. DOI: 10.1021/jf050962v.

Wang S.Y., Gao H. 2013. Effect of chitosan-based edible coating on antioxidants, antioxidant enzyme system, and postharvest fruit quality of strawberries (Fragaria $\times$ aranassa Duch.). LWT - Food Science and Technology 52(2): 71-79. DOI: 10.1016/j.lwt.2012.05.003.

Wongphan P., Harnkarnsujarit N. 2020. Characterization of starch, agar and maltodextrin blends for controlled dissolution of edible films. International Journal of Biological Macromolecules 156: 80-93. DOI: 10.1016/j.ijbiomac.2020.04.056.

Yang L., Paulson A.T. 2000. Effects of lipids on mechanical and moisture barrier properties of edible gellan film. Food Research International 33(7): 571-578. DOI: 10.1016/s0963-9969(00)00093-4.

Yang J., Yu J., Huang Y. 2011. Recent developments in gelcasting of ceramics. Journal of the European Ceramic Society 31(14): 2569-2591. DOI: 10.1016/j.jeurceramsoc.2010.12.035.

Yousuf B., Qadri O.S., Srivastava A.K. 2018. Recent developments in shelf-life extension of fresh-cut fruits and vegetables by application of different edible coatings: A review. LWT - Food Science and Technology 89: 198-209. DOI: 10.1016/j.lwt.2017.10.051.

Yu Y., Zhang S., Ren Y., Li H., Zhang X., Di J. 2012. Jujube preservation using chitosan film with nano-silicon dioxide. Journal of Food Engineering 113(3): 408414. DOI: 10.1016/j.jfoodeng.2012.06.021.

Zambrano-Zaragoza M.L., Quintanar-Guerrero D., Del Real A., González-Reza R.M., Cornejo-Villegas M.A., Gutiérrez-Cortez E. 2020. Effect of nano-edible coating based on beeswax solid lipid nanoparticles on strawberry's preservation. Coatings 10(3); 253; 11 p. DOI: 10.3390/coatings 10030253. 